\title{
Violence against Women and Resistance in Nawal El Saadawi's Woman at Zero Point and Alberto Moravia's The Woman of Rome
}

\author{
Nurul Hidayati \\ Universitas Negeri Surabaya \\ Surabaya, Indonesia \\ nurulhidayati10@mhs.unesa.ac.id
}

\author{
Budi Darma \\ Universitas Negeri Surabaya \\ Surabaya, Indonesia
}

\author{
Ali Mustofa \\ Universitas Negeri Surabaya \\ Surabaya, Indonesia \\ alimustofa@unesa.ac.id
}

\begin{abstract}
This research analyzes women violence and revealed by the main female characters in Nawal EI Saadawi's Woman at Zero Point and Alberto Moravia's The Woman of Rome. The research is qualitative study and the research used Foucault's theory of power relation. The data are in form of sentences related to women violence and resistance found in the novels. The results of the study are formulated as follows: first, the character Firdaus in Woman at Zero Point experienced violence not only by family members, but she also experienced violence in society in shape of sexual violence, psychological violence, and economic violence. While the character Adriana in The Woman of Rome also experienced violence but not as many as the character Firdaus does; second, the women resistance against violence in Woman at Zero Point is shown by the character Firdaus through her active actions by leaving her husband and other people who took own advantages toward her body, and ultimately killing a dangerous pimp; while in The Woman of Rome showed the resistance of the character Adriana through her passive actions. The two novels reveal both the perpetrators and the subject have taken advantages one another in their power relationship, the perpetrators have power in dominating the subject through violence over the body and sexuality while the subject exerted the power by forced cooperating by which the character Firdaus and Adriana have power to get free from the violence. This kind of relationship is commonly happened in the family and in society. Someone who has power is able to dominate over the people by using his or her authority. Therefore, it is obvious that the exercise of power exists in any kind of relations.
\end{abstract}

Keywords: violence against women, power relation, resistance

\section{INTRODUCTION}

Women are often considered as a weak and vulnerable person in family or society who is often expected to succumb to the male domination. And in the patriarchal system, family is presupposed a site where the domestic violence exists which the male domination always takes control over the women which cause women's subordination. Patriachal ideology also differentiates men and women biologically that men always have the dominant or masculine roles; and women always have the subordinate or feminine ones [1]. In line with Millet [1], Bhasin [2] stated that patriarchy literary means the rule of the father and it is originally used to describe a specific type of male-dominated family which included women, children, slaves, or domestic servants. But now the male domination generally refers to the power relationships by which men dominate women, and to characterize a system whereby women are kept subordinate women in a number ways which makes women lose their rights and opportunities in doing what they want or will. The system of patriarchy rejects their freedom over themselves. Thus, it can be stated that the patriarchal system is the rule of father law characterized by power and dominance in which men much more dominate, oppress and exploit toward women either in family or society.

In every human relationship, Foucault [3] said that no matter what kind of relationship it is, whether verbal communication involved or not, another relation which is a power relation exist. He [3] also stated power relation is a relation occurred because the existence of power. Thus, power has various forms and diverse sources. For Foucault, power is not limited to a specific action that is carried out by a specialized agency. Power can covers the whole life and is found in various areas of human life such as an individual, groups of people, or society. He [3] also stated that power is not something that someone possesses, but it is rather exercised which it is universal and exists in each of the particular kinds of social relations, while power relation lies within these relations.

Power relation also can be found in anywhere such as in family, or within an institution, or an administration [4]. The way to recognize the power relations within is by recognizing the resistance or possibility as well of changing the situation [5]. For Foucault [3], the forms of resistance can be seen from the characteristics of the resistances made by individuals. Humm [6] says that power is making people to do something 
that they otherwise would not. One cannot force others to act in a way that they actually would not to do it, however others are willing to do in a requested way does not mean that they really are. To say this kind of resistance is an adaptive response to power, which varies according to opposed power. Generally it comes first and specifically does not come into existence until power precedes it.

Foucault [3] also argued that people are in a situation where they always resist against something in their everyday lives, whether seeking for liberation against domination or self-formation process. Resistance is only conceptualized in terms of refusal. Within our understanding, however, to resist is not simply a contradiction but it is a creative process, a process to create and recreate, to change the situation, and once again to resist is actually to be an active member of that process. Resistance is actually a part of strategic relationship in which power exists. It always relies upon the situation against which it struggles.

In general, there are three types of resistance: (1) against forms of domination; (2) against forms of exploitation, against which ties individuals to herself to others in this way; (3) against forms of subjectivity and submission. This particular has been actually adopted in reality where the powerful people apply their rules upon the powerless. Consequently, the weak ones have become the vehicle of power. Their resistance or possible actions to fight against the rules, against the domination, forms of exploitation, and subjectivity and submission have become the evidence that power relations yet invisible but do exist [7].

The objects of this research study are Nawal El Saadawi's Woman at Point Zero, and Alberto Moravia's The Woman of Rome which have similar theme which it is about violence and resistance which depicts power relation in everyday relationship. Firdaus, the protagonist of Woman at Point Zero who lives in patriachal society while Adriana, the protagonist of The Woman of Rome lives under fascism regime, but these systemd have the same impact to the others; the people who have the authority exert their power which ultimately they subjugate the others by dominating and exploiting them for their own advantages. Both female characters experienced violence.

In his article, Fwangyil [8] said that the subordination that women experience in patriarchy system takes various forms such as discrimination, disregard, insult, control, exploitation, oppression, violence within the family, at the work place, or in society. In this system, Sultana [9] says that different kinds of violence such as sexual abuse, wife beating may be used to control and subjugate women by which male violence may be considered legitimate, while women always experience it, and the continued sense of insecurity that is instilled in women as result that keeps them bound to the home, economically exploited socially suppressed. In line with Fwangyil [8], Tesfaye [8] discussed the types of violence against women which adopted from Rebecca [10] and [1]. The violence are: a) sexual violence; b) phychological violence which is compatible with physical or verbal violence; and economic violence. which the damage done to a person in a form of sexual assault, it is not only physical injuries to her or his body but also trauma; c) financial violence or economic violence which men often have independent access to financial resources in such institution of family, women's right to earn is taken away by the family or the society's culture.

Foucault [7] affirmed that power is strategy that every human has their own goal, dream, and ambition. Strategy is applied in three ways: (1) applying strategy to designate the objective; (2) applying strategy as action to have the advantage over others; (3) applying strategy to obtain victory. Thus, in order to gain the goal, dream, and ambition, human needs strategies to obtain the victory. Once the goal is reached, it means the strategies are well played and applied. Some events there are obviously costs as the side effects of the strategies, but it depends on the strategy itself, the better the strategy applied, the less costs of the risks suffered.

Foucault [7] also argues that to resist is simply to say no. Above all, these forms of resistance are exercised in order to attack the particular form of power seeking for liberation under the domination and pressures. These forms of power can also categorizes the individual, marks the main woman characters to his own identity, imposes a law of truth on them that they must recognize and others have to recognize them. It is a form of power that makes individuals subjects. Foucault [7] underlines that there are two meanings of the word 'subject': (1) subject to someone else by control and dependence; and (2) tied to her own identity by conscience or self knowledge.

\section{METHOD}

Dealing with the achievement of an intended goal in answering the research problems on chapter one, the research entitled Women Violence and Resistance in Nawal El Saadawi's Woman at Point Zero and Alberto Moravia's The Woman of Rome uses Michel Foucault's concept of power relation which power is considered a name for a critical theoretical approach in analyzing literary works.

Power is not something that someone possesses, but it is rather exercised. It is universal and exists in each of the particular kinds of social relations, while power relation lies within these relations. Hence, it is essential to analyze the existence of resistance in order to examine the power exercise. By looking into the main woman characters' point of view or understanding the main woman characters' tone, it can be seen that one individual has completely exercised power over the other individuals. In this case, the power relation does exist. In the intended novels, Woman at Zero Point and The Woman of Rome, it shows how and where the power comes, how it is exercised on individuals in order to control the violence toward them, since they are as individuals are considered as the vehicle of power. The main objective of the resistance is to against the technique, which is a form of power that is exerted by the individuals. In general there are three types of resistance: against forms of domination, against forms of exploitation and against forms of subjectivity and submission. 


\section{RESULT AND DISCUSSION}

According to Ganley and Schechter [8], domestic violence is an epidemic affecting individuals which the perpetrator has purposeful and instrumental behavior. It is a pattern of abusive acts which directed to achieving compliance from or control over the victim and circumscribing the victim's life so that her independent thought and action are curtailed, so that the victim will become devoted to fulfilling the needs and requirements of the perpetrator. Tesfaye [11] discusses in her study about the types of violence against women related to Rebecca [12] and Lewis [5], they are: a) sexual violence; b) psychological violence is compatible with physical violence or verbal violence; c) financial violence or economic violence.

\section{A. Violence against Women Described in "Woman at Zero Point" and "The Woman of Rome"}

\section{a) Sexual Violence}

Firdaus often experiences being touched by her uncle in her childhood, "my uncle's hand moving slowly from behind the book he was reading to touch my legs" [10]. It is supported by Fwangyil [7] who adds that the moment Firdaus kneading dough that her uncle used any opportunity to exploit her sexually.

Firdaus also experiences a series of sexual violence in the public sphere after getting violence from her husband many times, she decides to escape and choose the street for her destination, but her decision now and then totally brings her to miserable life.

And when she lives in Bayoumi's house, she has been used by Bayoumi as sexual pleasure, "I felt the sudden touch of him, like a dream remembered from the distant past, or some memory that began with life" [10]. And when she asks for a job to Bayoumi, then he allowed his friend having her body on bed, "Who are you? ... You are not Bayoumi ... What difference does it make? ... do you feel pleasure?” [10].

In Sharifa's hands, a professional prostitute, Firdaus works for her as a prostitute, "Day and night, I lay on the bed, crucified, and every hour a man would come in" [4].

In the second novel, Adriana does not experience abuses as much as Firdaus. The more abuses she gets are derived from her mother who dominates and exploits her body and live. At the age of sixteen years old, Adriana is sent to a painter as an undressing model by her mother, “... she suggested I should pose for him ... after she had helped me to slip my clothes ... and had made me stand naked ..." [13]. Adriana mother thinks that Adriana is assets to getting money in order to support their living, and she never asks Adriana whether she desired to do it or not.

\section{b) Physical Violence}

Firdaus grows up in the family where her father daily dictates and maltreats his wife; therefore she ends up in a violent relationship with her husband, Sheik Mahmoud. The sexual relationship with her husband is rather tormenting. She endures this marital rape called sex instead of enjoying because men always see sexual pleasure as their sole right, "He leapt on me like a mad dog ... I surrendered my face to his face and my body to his body, passively, without any resistance, without a movement ..." [14].

In her marriage, Firdaus also experiences physical abuse which made her runs to her uncle's house for solace. But her uncle told her that all husbands beat their wives. Then she was turned back to her husband's house, but her husband's habit of beating is getting worse, "On one occasion he hit all over me ... my face and body became swollen and bruised ... he hit me with a heavy stick until the blood ran from my nose and ears", [14].

When she asks for a job to Bayoumi, she never gets it instead getting slapping and sexual exploiting. One night, Bayoumi's friend molested and asks her if she feels pleasure, Firdaus narrated that "I was afraid to say I felt nothing so I close my eyes once more and said, 'Yes' [14]. It is obvious that Firdaus felt trauma with the sexual and physical violence that she often experiences before. Bayoumi slaps her when she insists him to get a job, "... he jumped up and slapped me on the face; ... on the next moment he hit me with his fist in the belly so hard that I lost consciousness immediately" [14].

Once Adriana gets physical abuse from her mother, when she is back home from visiting Gino's employers' villa, Adriana is never out so late before which made her mother so furious, "... it was she, dragged me ... threw me onto sofa and began to strike me with her fists, in a tempest of fury, ... always found a way of hitting me a nasty blow from underneath that got me full in the face" [13].

Female circumcision or female genital mutilation which generally understood as the removal of some or all of the female genital is a common traditional practice in African societies. Firdaus' mother brought to her with carrying a small knife, "They cut off a piece of flesh from between my thighs", [14]. Firdaus does not know what the cutting is for, later, in her life, she is unable to experience sexual pleasure, “... a part of me, of my being, was gone and would never return” [14].

Related to Fwangyil [8], wife battering is also traditionally accepted and the wife is not supposed to complain because culture demands that she submits to male authority. The husband is justified beating his wife; "he hit me with his heavy stick until the blood ran from my nose and ears" [14]. And the religion also permits such punishment if the wife does not obey the husband, as a wife, her "duty was perfect obedience" [14]. Because of this tradition, Firdaus thinks that she is powerless to stand up to her husband violence.

Ganley and Shcechter [15] in Fwangyil say emotional or psychological abuse which the verbal attacks and other tactics of control are intertwined with the threat of harm leads the perpetrator dominates in the relationship through fear [5].

When a policeman approaches Firdaus and says, "You're a prostitute, and it's my duty to arrest you, and other of your kind. To clean up the country, and protect respectable families from the likes of you" [10]. This quote depicts that the policeman believes he is of a higher social class than Firdaus, a prostitute, so he uses his power over her and forces her to serve him at his home. 
And when Di'aa, her journalist friend, tells Firdaus, "You are not respectable" [10]. This affects Firdaus in a big way so much. Di'aa believes that he and other women are more respectable than a prostitute, so he uses his power against Firdaus.

In Adriana's tale, Adriana also experiences verbal violence. When she arrives home, and directly tells her mother about Gino's proposal, her mother suddenly shouts "I'll kill you!" [13]. And Adriana knows when her mother's fury increased and the threat appeared more actually; she would be better to stay away from her while Adriana watches every movement of her mother, "she was really capable of hurting me with the first thing that she happened to pick up ... she suddenly began waving her dressmaking scissors, the large ones ..."'[13].

And Adriana's mother often scolds her, "You were the ruin of me"; "If it had not been for you, I would not have married that man ..." [13]. In other words, it can be inferred from what her mother arranged plans for her future that Adriana should be obedient to her in order to fulfill her needs and requirements like she did to her who did not dare to prevent Adriana's birth, thus she had been obliged to marry Adriana's father.

\section{c) Economic Violence}

When Firdaus is about eighteen, she is forcedly married to Sheik Mahmood, a sixty year old rich widower with deformity on his face. This arrangement is masterminded by her uncle's wife who expects a big dowry from this arrangement. As her uncle's wife says "... I intend to ask him for a big dowry" [14]. Because her uncle's wife does not like her to stay any longer in their house and to prevent her husband sending Firdaus to university because she thinks that it will cost much money.

And when Firdaus becomes a young novice in Sharifa's hands, a professional prostitute,Sharifa takes care of her as like a mother. She also motivates Firdaus to be stronger than life itself. It no longer, Firdaus becomes a prostitute for Sharifa, but she does not have an authority asking something from a man because Sharifa exploits her day by day, "Don't ask for anything. That's not your affair. It's mine" [14], "Day and night, I lay on the bed, crucified, and every hour a man would come in" [14]. She does not get anything from her profession as a prostitute.

Living in poverty makes Adriana's mother arranges such plans for Adriana's future in order to get a better life than hers. She believes that Adriana is the only asset that she can use to earn money. Adriana is sent to a painter as a naked model. When the painter tells her that her mother loves money more than anything, she directly answered that "I was born poor and she wants me to earn a good living” [13].

Adriana gives all the money she earned to her mother, "I used to give mother all the money I earned..." [13], and when she is not posing in the studio, she stays at home all day helping her mother cutting and sewing shirts, “... and the rest of the time, when I was not naked, stiff ... I sat bent over the sewing machine..." [13]. It is in line with Hartman [16], what Adriana did as a help to her mother supporting their life over poverty was a portrayal of domestic violence which including economic abuse.

Nevertheless, Adriana's mother does not feel enough and keeps trying to get Adriana another job as a dancer, "According to her, my earnings were too small; ... Mother suddenly conceived the ideia that I might become a dancer" [13]. This obviously depicts that Adriana was economically exploited by her mother by manipulating her attention and thinking about Adriana's future, instead of being dissatisfied with Adriana's profession as a model long before.

\section{B. Women Resistance Described in "Woman at Zero Point" and "The Woman of Rome"}

\section{a) Resistance against forms of domination}

Firdaus' resistance against her husband's habit of beating her is by leaving the house, "So I left the house and went to my uncle... was a respected Sheikh, well versed in the teachings of religion; ... could not possibly be in the habit of beating his wife" [14]. It can be inferred that Firdaus exerts her power to defense herself by delivering her opinion about her husband's violence to her uncle and aunt, "If I dropped the packet of soap powder and spilled a few grains on the floor, he would jump up from his chair and complain at me for being careless" [14]. By telling this, Firdaus thinks that she would get a way to be free from the dominated husband who always complains and tortures her on everything she does the house works.

Firdaus realizes that her husband's habit of shouting and beating her never ends then she decides to escape, "So I left, but this time I did not go to my uncle's house. I walked through the streets..." [14].

When Firdaus is under Bayoumi's power, she realizes that she is being used, then “... I ran out of Bayoumi's house ... For the street had become the only place in which I could seek refuge, and into which I could escape with my whole being" [14]. Firdaus thinks that the street was only safe place for her being free from men whom always exploit her for their own advantages and in order to save herself from sexual violence.

Adriana resists her mother's power of dominating her by understanding the condition of her mother. Later, Adriana realizes that she has been advantaged by this condition because she is delighted when she sees many visitors come to the studio seeing her beauty and body as like her mother's allusion, "These glances, as well as mother's veiled allusions, roused my sense of coquetry and made me conscious both of my beauty and of the advantages I might draw from it. ... I could not help feeling delighted when I saw how excited the visitors became..." [13].

\section{b) Resistance against forms of domination}

Firdaus resists against Sharifa domination by leaving the house as she did before from Bayoumi, “... and hurried down the flights of stairs into the street" [14].

And when Firdaus already becomes a popular prostitute, her friend, a journalist named Di'aa visited her in her private library. They were involved on talk about Firdaus' profession which later becomes an echo in Firdaus' ears. Di'aa talks 
Firdaus that her profession is not a respectable job. It suddenly makes Firdaus insulted. But she is hard thinking of it, "I still had my secondary school certificate ...to find respectable work. ... Every time there was an advertisement I applied for the job. I went to all the ministries, departments, and company offices where there might be a vacancy. ... I at last found a job with one of the big industrial concerns" [14]. It is something she has not known yet before that she is not a respected woman. After some time she leaves everything she has. She stays in a small room without a toilet. And she tries to get a job.

Firdaus comes back to her old profession after realizing that even she is not becoming a respectable woman though she works at an office. But then a dangerous pimp, Marzouk, wants to protect Firdaus from other men, but Firdaus refused him, then he threatens her and wants to take her in order to get own advantages, "every prostitute has a pimp to protect her from other pimps, and from the police... I may be obliged to threaten" [14]. They keep verbally fighting. The situation is getting worse. Firdaus wants to leave her house, but Marzouk prevents her.

Finally, Marzouk is dead on the hands of Firdaus, "His hand started to reach for the knife he carried in his pocket, but my hand was quicker than his. I raised the knife and buried it deep in his neck, pulled it out of his neck and then thrust it deep into his chest, pulled it out of his chest and plunged it deep into his belly. I stuck the knife into almost every part of his body. I was astonished to find how easily my hand moved as I thrust the knife into his flesh, and pulled it out almost without effort" [14]. It is obviously that Firdaus resist Marzouk's power and tries to be free from his intention having her as his prostitute because she does not want to be exploited by anyone anymore.

Adriana's resistances toward her mother's power in dominating her body and live are mostly invisible, because she never has any courage, even just for asking her mother for a reason of why she has arranged all plans on her. She always speaks to herself, "I understood from various hints..." [13].

Adriana is always silent when her mother talks to the painter, and tries to persuade him for employing Adriana as his model by saying, "Where else will you find legs and hips and breasts like this?" [13]. There is nothing Adriana can do, except understanding he mother, "I realized mother was not talking in this way out of spite but that she was proud of my beauty because she was my mother ..."[13]. Though in this situation she is ashamed but she keeps on posing.

When the painter tells Adriana that her mother only loves money more than her in this world, Adriana says, "No, no, that's not true. She loves me best of all, but she's sorry I was born poor and she wants me to earn a good living" [13]. By understanding her mother, "Today, seeing things from a certain distance, I really cannot bring myself to say she was wrong" [13], and by saying this, she tries to resist the truth that her mother's power of dominating her by understanding her mother.

\section{submission}

c) Resistance against forms of subjectivity and

In patriarchal tradition, women are supposed to succumb to the traditional blackmail that "A virtuous woman was not supposed to complain about her husband. Her duty was perfect obedience" [14], in other words, women are taught to be submissive wives and dutiful mothers without questioning the subjugating acts of the men over themselves [5]. In line with this notion, in Tesfaye [11], Humm [6] stated that the ideal woman in the most patriarchal society is the one who is beautiful quiet and obedient. And the perfect woman is pure and sweet with a caring and loving heart. Her place in men's life is as a 'nurture care taker and helpmate'. Thus according to Ruthven [9], a woman is expected to be passive rather than to be bold and ambitious.

When Firdaus goes to her uncle's house after being hit by her husband, she tells her uncle and wife about her husband's assault physically over herself. But they even do nothing instead reminding Firdaus that a husband is justified battering his wife, and as his wife, she is not supposed to complain. Firdaus is forced to accept this condition as her status in the society that she is never equal to a man, and her existence is only to help her husband live more effectively.

Throughout her mother's domination in her life, Adriana is never disobedient toward her mother's plans. She always does what her mother said, especially for being an undressing model to various artists. Though she obeyed her mother physically, but inside her heart she did not agree for plans that were arranged by her mother over her life. Adriana is vulnerable by her mother domination. Mostly, she could not do something except understanding her mother for treating her like what her mother wanted.

When her mother referred to her birth, her often used to say, "You were the ruin of me ... If it had not been for you, I would not have married that man, and by now I'd have had my own car" [13]. This complain absolutely hurt her because she does not know anything about her mother's past, thus she only grasp the meaning by herself without having any courage to ask her mother directly. Then she understood that, “... as she pondered over her own life in this way, she did not want her daughter, who was so much more handsome, to make the same mistakes and incur the same fate" [13].

Every time her mother shout or complain about the life, she would better to listen to her and keep her away from her mother because she always notice that her mother is able to hurt her with something around her, as she narrates, "I knew she a was quite uncontrolled when she had these fits, and was really capable of hurting me with the first thing that she happened to pick up ... she suddenly began waving her dressmaking scissors, the large ones, and I was only just in time to dart aside as the scissors passed me and hit the wall" [13].

\section{CONCLUSION}

Foucault's ideas of power are represented in novels of Woman at Zero Point and The Woman of Rome which commonly exist between people in the real life. In the novels, 
both the perpetrators and the subjects exercise their power which is set of strategies they apply in gaining the victory. The perpetrators are considered as the agents of power who exercise power upon the subjects. Since power is sets of strategies which applied upon the other people, therefore, power in these novels described on how the strategies are applied by the characters. In practice, the perpetrators have their goals to dominate and exploit over the subjects in order to get their own advantages without having a heart or ignoring the suffering that the subjects must undergo. By understanding their conditions being dominated and exploited by others, the protagonists as subjects exert the power through resistances against the violence

Above all, the power in the two novels is sets of strategies applied by both the perpetrators and the subjects in gaining the victory in which the power is being exercised. However, the Foucault's ideas of power are represented in the two novels which can be as symbols of social relation between people in the real life.

In the link of the real life, the two novels represent the portrayal of the relationship in the real life where the people have the relation one another, and the problems of life often occur among the relations. Thus, the violence against women can be symbolized as the common problems appear in the real society that every people may employ their strategy to gain their victory or simply to survive which these struggles are applied upon the other people. In short, power truly exists in every social relation, and power is exercised among the people among them.

The perpetrators are as the symbol of the persons who have the power and exercise it to dominate and exploit upon the persons they want to be deserved as their vehicles of power in order to gain their victory. While the subjects are considered as the symbol of those who are vulnerable, so they are often used as the vehicles of power.

\section{REFERENCES}

[1] L. Lewis, Bringing Equality Home: Implementing the Convention on the Elimination of All forms of Discrimination Against Women. New York: The United Nations Development Fund for Women, 1998.

[2] K. Bhasin, What is Patriarchy. New Delhi: Women Unlimited, 2006.

[3] M. Foucault, The Essential Works of Foucault Vol. 1. New York: The New York Press, 1997.

[4] K. Millet, Sexual Politics. London: Virago, 1977.

[5] M. G. E. Kelly, The Political Philosophy of Michel Foucault. New York: Rouledge, 2009.

[6] M. Humm, Modern Feminism: Political Literary, Cultural. New York: Columbia University Press, 1992.

[7] M. Foucault, The Essential Works of Foucault (R. H. a. Others. Trans. J. D. Faubion Ed. Vol.3). New York: The New York Press, 2001.

[8] G. A. Fwangyil, "Cradle to Grave: An Analysis of Female Oppression in Nawal El Saadawi's Woman at Point Zero," Int. J. Lnguage, Lit. Gend. Stud., vol. 1, no. 1, pp. 15-28, 2012.

[9] K. K. Ruthven, Feminist Literary Studies: an Introduction. Great Britain: Cambridge University Press, 1984.

[10] C. Rebecca, Human Rights of Women: National and International Perspectives. Philadelphia: University of Pennsylvania Press, 1994.

[11] H. Tesfaye, The Impact of Partriachy on Female Characters in hh Soy $\Pi 77 C$ (Beyond the Horizons) and Woman at Point Zero a Feminist Criticism Approach: A Comparative analysis. Addis Ababa University, 2010.

[12] S. Mills, Michel Foucault. London: Routledge, 2003.

[13] A. Moravia, The Woman of Rome (Trans. Holland, L.). New York: Farrar, Straus and Company, 1949.

[14] E. N. Saadawi, Woman at Point Zero. New York: Zed Books Ltd, 1983.

[15] S. Ganley, A. L. \& Schechter, Domestic Violence: A national Curiculum for Family Preservation Practitioners. Family Violence Prevention Fund, 1995.

[16] H. I. Hartman, "The Family as the Locas of Gender, Class and Political Struggle: The Example of House Work," Signs (Chic)., vol. 6, no. 3, pp. 366-394, 1981. 